\title{
Detecting osteoporosis in elderly women with panoramic radiography technique
}

\author{
Barunawaty Yunus, ${ }^{*}$ Rezky Amalia
}

\section{Abstract}

Objective: Osteoporosis is a systemic disease which characterized by a reduction in bone mass with deterioration microarchitecture of bone and degradation of bone tissue which can raise loss of bone. 0steoporosis process actually begin at the age 40-50 years. The technique can be used to detect osteoporosis by performing panoramic radiographic examination techniques. The aim of this study is to detect the presence of osteoporosis in elderly women using panoramic radiography techniques. Material and Methods: The subjects of this study is image results of a panoramic radiography with vulnerable women aged 50-70> obtained from the Radiology Hospital section of Hasanuddin University, Mental Index measurement is then performed on image results of the panoramic radiographs.

Results: Overall regardless of age, the prevalence of osteoporosis reached $10 \%$ per 100 population ( $p>0.05$ ).

Conclusion: In detecting osteoporosis in elderly women, panoramic radiography can be applied. The index used is Mental Index, an index of panoramic radiography has been developed to detect osteoporosis.

Keywords: Elderly, Osteoporosis, Panoramic radiography

Cite this Article: Yunus B, Amalia R. 2016. Detecting osteoporosis in elderly women with panoramic radiography technique. Journal of Dentomaxillofacial Science 1(3): 155-157. D0l:10.15562/jdmfs.v1i3.308

Department of Dental Radiology, Faculty of Dentistry, Hasanuddin University, Makassar, Indonesia
*Correspondence to:

barunawaty@yahoo.com

Received: 17 September 2016 Revised: 15 November 2016 Accepted: 22 November 2016 Available Online: 18 December 2016

\section{Introduction}

Osteoporosis is a disease which related to the aging process and unconsciously because the decrease of mass bone might occur annually without any symptoms. Some symptoms might only be detected when it's on the continuous stage. Osteoporosis is a systemic disease which characterized by mass bone reduction, micro bone reduction, and bone tissue quality reduction which cause bone loss. It is highly risk condition because the bone become fragile and easy to broke even fractures. ${ }^{1}$

Osteoporosis process begin at 40-50 years old, when man and woman will experience mass bone reduction process. ${ }^{2,3}$ Mass bone decrease 5-10\% each decade, but this process occurs faster in women after menopause and more often occur in women than men. Osteoporosis not only related to menopause but also related to other factors such as smoking, small body posture, less activity, sun light radiation, drug decreased bone mass, low-intake calcium, caffeine and alcohol consumption, and diabetes mellitus disease. ${ }^{4-6}$

Gold standard in diagnosing osteoporosis is Bone Mineral Density (BMD) because it is the best predictor to bone fracture; commonly measured with Dual Energy X-ray Absorptiometry (DXA) assays which stated as the best equipment detecting osteoporosis recently. ${ }^{7-9}$ The problem in Indonesia that the availability of DXA hardware is limited to a big hospital and its uneasy to conduct a special diagnosis using DXA. ${ }^{10-13}$
Technique applied to detect osteoporosis is radiography assay with panoramic technique. Panoramic radiography is one of extra oral pictures often used by dentist because perform complex structural picture of oromaxilofacial which help to gain diagnosis for care planning.

\section{Material and Methods}

This analytic observational study with cross-sectional design conducted in March-May, 2015 and located in Dental Hospital Hasanuddin University. Samples are women visited radiology installation of Dental Hospital Hasanuddin University, aged above 50 years old and meet criteria of women aged 50-80 years old, do not perform systemicalabnormality and optimum oral hygiene. Total samples are 30 people.

Osteoporosis in this study measured by cortex mandibular width. Meanwhile, cortex mandibular width observed through panoramic rontgen photo. Mandibular cortex width measured in 2 regions, those are left and right region. Then, measurement of both region is accumulated to gain mandibular cortex width as a whole. Mandibular cortex width in measured in millimeter unit $(\mathrm{mm})$. All results collected then analyzed with SPSS 18.0 (SPSS Inc., Chicago, IL., USA) program.

Tools and materials applied are panoramic radiography (cranex D), apron, caliper, protactor and panoramic photo result. Qualified subjects 
are mentioned about study procedure and then asked for signing the informed consent. Panoramic photo processed digitally. Panoramic photo results then measured their cortex mandibula's thickness. The thickness of cortex mandibular is measured in parallel line (a line along with teeth axis and interception at the edges of mandibular). That line is perpendicular with tangent line near mandibular and intercepted with the side of foramen mentalis inferior. Measurement conducted using caliper $(\mathrm{mm})$

\section{Results}

This study is conducted to 30 elderly women, aged 50-80 years old. Samples divided into 3 different age categories, those are 50-59 years old, 6069 years old and $70-79$ years old.

The distribution of the mean of mandibular cortex width in left, right and the average of both regions showed that samples total in each categories are similar, that is 10 samples (33.3\%) consist of 50-59 years old, 60-69 years old and 70-79 years old. Table 1, mandibular cortex width results are also shown in this study. The study result to the width of mandibular cortex in left, right and the average of both regions perform that mandibular cortex width in left region is the highest at 50-59 year old. Similar result showed in mandibular cortex width in right region and as a whole (average of both region). In both regions also shown reduction of mandibular cortex width followed by aged category increasing. The mandibular cortex width in left region at

Table 1 Average distribution of the result of cortex mandibular width in left, right, and the average of both regions

\begin{tabular}{llccc}
\hline & & \multicolumn{3}{c}{$\begin{array}{c}\text { Mean and SD of Mandibular cortex width } \\
\text { measurements }(\mathbf{m m})\end{array}$} \\
\cline { 3 - 5 } & & Left region & Right region & Mean of the region \\
\hline 50-59 years old & $10(33.3 \%)$ & $4.33 \pm 0.83$ & $4.18 \pm 0.57$ & $4.15 \pm 0.73$ \\
$60-69$ years old & $10(33.3 \%)$ & $3.92 \pm 0.60$ & $4.07 \pm 0.68$ & $3.99 \pm 0.62$ \\
$70-79$ years old & $10(33.3 \%)$ & $3.43 \pm 0.81$ & $3.51 \pm 0.75$ & $3.46 \pm 0.77$ \\
Total & $30(100 \%)$ & $3.89 \pm 0.82$ & $3.92 \pm 0.71$ & $3.46 \pm 0.77$ \\
\hline
\end{tabular}

Table 2 The distribution of Osteoporosis occurrence based on the age categories

\begin{tabular}{lcccc}
\hline & \multicolumn{3}{c}{ Osteoporosis occurrence } \\
\cline { 2 - 3 } & Osteoporosis & & Without osteoporosis \\
\cline { 2 - 2 } & $\mathbf{n ( \% )}$ & $\mathbf{n}(\%)$ & $\mathbf{n}(\%)$ \\
\hline $50-59$ & $0(0 \%)$ & & $10(100 \%)$ & $10(33.3 \%)$ \\
$60-69$ & $1(10 \%)$ & & $9(90 \%)$ & $10(33.3 \%)$ \\
$70-79$ & $2(20 \%)$ & & $8(80 \%)$ & $10(33.3 \%)$ \\
Total & $3(10 \%)$ & & $27(90 \%)$ & $30(100 \%)$ \\
\hline
\end{tabular}

50-59 years old reach $4.33 \mathrm{~mm}$, at 60-69 years old decrease to $3.92 \mathrm{~mm}$ and at 70-79 years old reach 3.43 years old. Meanwhile, in right region, mandibular cortex width at 50 -59 years old reach 4.18 $\mathrm{mm}$, at 60-69 years old decrease to $4.07 \mathrm{~mm}$ and at 70-79 years od only reach 3.51 years old. As a whole (the average of both region), the mandibular cortex width aged 50-59 years old, $60-69$ years old and $70-79$ years old are $4.51 \mathrm{~mm}, 3.91 \mathrm{~mm}$ and $3.46 \mathrm{~mm}$ respectively.

The distribution of osteoporosis occurrence based on aged categories shows that, in 10 samples aged 50-59 years old, no one experience osteoporosis, meanwhile at 60-69 years old, 9 samples (90\%) do not experience osteoporosis and 1 person (10\%) experience osteoporosis. Table 2 Thus, at 70-79 category, from 10 samples, there are 2 samples (20\%) who experiences osteoporosis and the other 8 samples do not experience osteoporosis or in a healthy condition. As a conclusion, without seeing the age, there are 3 from 27 samples (30\%) which experience osteoporosis.

\section{Discussion}

This study conducts panoramic radiography as the study media because it can perform all the pictures of mandibular in a film. Panoramic radiography is a choice in detecting early osteoporosis because it is easier to conduct, equipment availability and affordable price. ${ }^{12}$

The study results perform that there is an increasing prevalence of osteoporosis along with the age. No one experience osteoporosis at 50-59 years old and $10 \%$ experience osteoporosis at 60-69 years old. It occurs because the estrogen reduction pasca menopause as well as the bone density reduction will be faster. During first 5-10 years after menopause, women might conduct mass bone reduction as many as $2-4 \%$ each year. It means that they will loss bone mass as many as $25-30 \%$ in this period. The acceleration of bone mass reduction pasca menopause is the main reason of osteoporosis in women. Life style factors including smoking, alcoholic drinking, soda drinking, coffee drinking, less sport activity and less milk drinking may increase osteoporosis risk. This is proven in the research conducted in North Sulawesi, Yogyakarta and West Java in 2008. ${ }^{11}$

This study conducts panoramic radiography as the study media because it can perform all the pictures of mandibular in a film. Panoramic radiography is a choice in detecting early osteoporosis because it is easier to conduct, equipment availability and affordable price. ${ }^{12}$ Panoramic radiography pictures in maxilla bones and mandibular, then it can be used to detect bone mass risk. Some indexes 
have been developed in scoring and measuring the mandibular bone mass quality and to observe resorption signs in panoramic radiography, they are: Panoramic Mandibular Index (PMI) is the width of mandibular divided by foramen mental distance to cortex inferior mandibular, Mandibular cortex Index (MCI) is a classification of mandibular morphology, pictures the porosity of mandibular and related to mandibular mass bone, Mental Index (MI) I is the width of mandibular cortex based on foramen mental position.

One way applied to measure the mass bone quality of mandibular is by mental index. Mental index is the average width calculated bilaterally in panoramic radiography under foramen mental area which located between P1 and P2, that is by measuring mandibular cortical which is made from perpendicular line from mental foramen to the parallel line which pass the edge of cortical mandibular superior and inferior. Sample diagnosed as osteoporosis based on mental index if it $\leq 3 \mathrm{~mm} \cdot{ }^{12,14}$

\section{Conclusion}

Based on the study, we concluded that osteoporosis can be detected by panoramic radiography technique with mental index. The study proof that the highest prevalence of osteoporosis shown at the age of 70-79 years old, that is $20 \%$. This study also proofs that the increasing prevalence along with the increasing of the age.

\section{Conflict of Interest}

The authors report no conflict of interest.

\section{References}

1. Jahari AB, Prihatini S. Risiko osteoporosis di Indonesia. Jakarta: Puslitbang Gizi dan Makanan Depkes RI; 2007. p. $1-11$.
2. Utomo M, Meikawati W, Putri ZK. Faktor-faktor yang berhubungan dengan kepadatan tulang pada wanita post menopause. Fakultas kesehatan UNISMUH Semarang 2010;6.

3. Boeltrelia. Manifestasi osteoporosis di rongga mulut. J Dentofas 2003;1: 174-177.

4. Noerjanto RPB, Saputra D, Yusuf YT. Sensitivitas, spesifitas, dan akurasi pengukuran sudut antegonial pada radiografik panoramic penderita osteoporosis. Dentomaxillofac Radiol 2014;5: 1-7.

5. Yunus B. Keterbatasan Radiografi Panoramik dalam pengukuran ketidaksimetrian mandibular. J Dentofasi 2007;6: 16-20.

6. Rotikan TM. Mengapa osteoporosis dapat menyerang kita?. In Setyohadi B, editor. Osteoporosis dan penyakit metabolik. Ilmu kedokteran Olahraga FKUI. Jakarta: PEROSI; 2012. p. 1-3.

7. White SC. Oral radiographic predictors of osteoporosis. Dentomaxillofac Radiol. 2002;31: 84-92.

8. Permana H. Patogenesis dan metabolisme osteoporosis pada manula. Bandung: FK UNPAD; 2014.

9. Kawiyana IKS. Osteoporosis pathogenesis diagnosis dan penanganan terkini. Jurnal Penyakit Dalam 2009;10: 157-170.

10. Setyohadi B, Hutagalung EU, Adam J, et al. Panduan diagnosis dan penatalaksanaan osteoporosis. Jakarta: PEROSI; 2010. p. 1-2.

11. Prahatini S, Mahirawati VK, Jahari AB. Faktor determinan risiko osteoporosis di tiga provinsi di Indonesia. Media Litbang Kesehatan 2010;20: 91-99.

12. Noerjanto RPB, Savitri Y, Putri MC. Sensitivitas, spesifitas, dan akurasi pengukuran mentale indeks pada radiografi panoramic wanita pasca menopause. Dentomaxillofac Radiol 2014;5: 8-13.

13. Azhari, Suprijanto, Diputra Y, et al. Analisis citra radiografi panoramik pada tulang mandibula untuk deteksi dini osteoporosis dengan metode Gray Level Cooccurence Matrix (GLCM). MKB J 2014;46: 207.

14. Hastar E, Yilmaz HH, Orhan H. Evaluation of mental index, mandibular cortical index and panoramic mandibular index on dental panoramic radiographi in the elderly.

15. Pasler, Friedrich A. Color atlas of dental medicine. Radiology. Thieme. 2006.

16. Lukman M, Juniarti N. skrining osteoporosis: hubungan usia dan jenis kelamin dengan kejadian osteoporosis di Desa Cijambu Kecamatan Tanjungsari. Skrining osteoporosis: Hubungan Usia dan Jenis Kelamin 2009;10: 18-19.

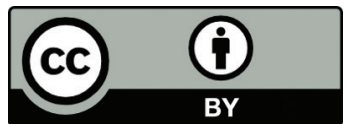

This work is licensed under a Creative Commons Attribution 